\title{
A GIS-Based History of Gold Mine Residue Deposits and Risk Assessment of Post-Mining Land-Uses on the Witwatersrand Basin, South Africa
}

\author{
M.W. Sutton School of Animal, Plant and Environmental Sciences, University of the Witwatersrand, South \\ Africa
}

I.M. Weiersbye School of Animal, Plant and Environmental Sciences, University of the Witwatersrand, South Africa

J.S. Galpin School of Statistics and Actuarial Sciences, University of the Witwatersrand, South Africa

D. Heller Bar-Kal Systems Engineering, Israel

\section{INTRODUCTION}

In 1886, an Australian prospector named George Harrison discovered gold in the Main Reef Conglomerates on the farm Langlaagte, which now falls within the present day City of Johannesburg. Since then, hundreds of mine residue deposits (MRDs) have been built across the Witwatersrand Basin. By the mid-1970s, gold recovery processes had improved sufficiently to also allow residual gold from old MRDs to be recovered at a profit. This resulted in dump reprocessing operations and the clearing of soils previously covered by MRDs ('footprints'). Estimates put the area of MRDs and 'footprints' at between 400 and $500 \mathrm{~km}^{2}$, comprising some 6 billion t of tailings (Chevrel et al., 2003), containing approximately $430000 \mathrm{t}$ of low-grade uranium (Winde et al., 2004) and 30 million t of sulphur (Witkowski and Weiersbye, 1998).

Historically, mining companies often located MRDs in sensitive areas and employed no pollution control. Acid mine drainage (AMD) is associated with Witwatersrand gold mines and MRDs (Maree et al., 1996), and contamination from gold mining has been identified many kilometres downstream from the original sources (Naiker et al., 2003). An argument on the environmental merit of dump reprocessing is that this provides opportunity to relocate residues to more appropriate and better contained sites. However, there is also evidence that reprocessing exacerbates contamination though exposure of previously anaerobic tailings to air and water (Tutu et al., 2005).

With the curtailing of mining activities and clearing of land previously covered by MRDs, there comes a demand to use this land for residential, agricultural or industrial purposes. In South Africa, the right to an environment not harmful to a person's health and wellbeing, and the right to the protection of the environment are basic constitutional human rights (s24 of the Constitution of the Republic of South Africa 108 of 1996). Thus there is a need to understand the extent and types of contamination, and the potential risks associated with different land-uses not only on mining land after closure, but on other affected land.

Baseline environmental conditions were rarely established prior to commencing with mining operations and subsequent dump reprocessing. In order for such operations to achieve mine closure it is necessary that they obtain agreement with Government regarding the limits of their liabilities, which could originate from up to 120 years of mining by numerous companies, many of which no longer exist. Historical aerial photographs and satellite-based earth observation systems are powerful tools that have been used to establish culpability (such as in the case of the failure of the Merriespruit slimes dam), but also have the potential to demonstrate absence of liability via mapping of historical contamination that pre-dates current mining operations.

The aim of this study is to determine the adequacy of historical aerial photographs and satellite thematic imagery (TERRA satellite ASTER images), integrated with geographic information systems (GIS)-based metadata, for visualising historical contamination emanating from MRDs in a representative semi-arid gold and uranium-mining region (the East Rand of Johannesburg). This aim is of value in establishing standardized tools for mapping mine impacts, in order to focus environmental cleanup, demonstrate compliance, and assist in closure planning. 


\section{METHOD}

We performed an environmental classification of MRDs using ESRI ${ }^{\circledR} \operatorname{ArcGIS}^{\mathrm{TM}}$ version 8.3 software, and a basic risk assessment of land-use using $\mathrm{SAS}^{\circledR}$ Enterprise Guide ${ }^{\circledR}$ version 3.0.0. statistical analysis software. Selected sites within the Ekurhuleni Metropolitan Municipality (EMM) were chosen for the study. Sections of two major goldfields fall within the EMM: the Central Rand Goldfield and the East Rand and Heidelberg Goldfield. The EMM is the largest industrial area in South Africa and a century ago was the world's largest producer of gold. However, gold mining now contributes only about $2 \%$ to the economy of the EMM.

\subsection{Data Acquisition}

\subsubsection{Aerial photographs}

We obtained aerial survey photographs (orthorectified and geo-referenced) taken in February 2003 from the Development Planning Department Corporate Office of EMM. Historical aerial photographs for 1938 and 1964 were obtained from two other sources (Table 1). The 1938 hard copy photographs had been scanned at 450 dots per inch (dpi) producing an equivalent ground sampling distance of $1 \mathrm{~m}$. Images were orthorectified with a $10 \mathrm{~m}$ digital elevation model (DEM) generated from $5 \mathrm{~m}$ contours with TOPOGRID in ARC/INFO and mosaicked using hot-spot removal and colour-balancing between overlaps. Hard copy photographs for 1964 were scanned at 800 dpi, orthorectified and geo-referenced using $\mathrm{ESRI}^{\circledR} \operatorname{ArcGIS}^{\mathrm{TM}}$ 8.3.

Table $1 \quad$ Historical aerial photography

\begin{tabular}{|l|l|l|l|l|}
\hline Area & Company & Date & Scale & Access \\
\hline $\begin{array}{l}\text { West and East } \\
\text { Rand }\end{array}$ & $\begin{array}{l}\text { South African Defence Force imagery } \\
\text { Chief Directorate: Surveys and Mapping } \\
\text { archive imagery; Orthorectification by the } \\
\text { Centre for Geographical Analysis, } \\
\text { Stellenbosch University }\end{array}$ & $\begin{array}{l}\text { May to } \\
\text { September } \\
1938\end{array}$ & $1 / 18000$ & $\begin{array}{l}\text { Council for } \\
\text { Geosciences }\end{array}$ \\
\hline $\begin{array}{l}\text { Witwatersrand } \\
\text { Sine Dump }\end{array}$ & $\begin{array}{l}\text { Aircraft Operating Co. (Aerial Surveys) Ltd } \\
\text { EMPR Services, Johannesburg archive } \\
\text { imagery }\end{array}$ & $\begin{array}{l}\text { October and } \\
\text { November } \\
1964\end{array}$ & $1 / 9000$ & $\begin{array}{l}\text { Chamber of } \\
\text { Mines }\end{array}$ \\
\hline East Rand & Unrecorded & $\begin{array}{l}\text { February } \\
2003\end{array}$ & - & EMM \\
\hline
\end{tabular}

\subsubsection{Satellite imagery}

Multi-spectral remote sensing (MSRS) imagery acquired by the ASTER sensor on the TERRA satellite was acquired from the National Aeronautical and Space Agency (NASA, U.S.A.). Four ASTER images were interpreted for minerals (pyrophyllite; chlorite; jarosite; copiapite and uranium-bearing minerals), and for the normalized difference vegetation index (NDVI, an index of plant chlorophyll and productivity), using the Very Near Infra Red (VNIR)- Short Wave Infra Red (SWIR) region of the sensor (band 1-9, 0.55-2.39 $\mu \mathrm{m}$ ):

- $\quad$ AST_L1B.003:2018226064, 25 Oct 2003.

- AST_L1B.003:2019016590,07 Jan 2002.

- AST_L1B.003:2008705798, 06 Oct 2002.

- AST_L1B.003:2012471587, 31 Mar 2003.

Atmospheric corrections of imagery were performed using the ATCOR 2.3 model (DLR-German Aerospace Centre), which accounts for approximately $80 \%$ of typical atmospheric data obtained by satellite imagery (Richter, 2003). The result of running the ATCOR model is reflectance data imagery. In addition, we used 
ground measurements to improve the reflectance accuracy. Ground target spectra were measured on bare soil in the area with a field spectro-radiometer, and adjusted to ASTER spectral resolution using ENVI 4.2 software. We used an un-mixing method to identify the minerals; with reference spectra for each mineral taken from the following sources:

- United States Geological Survey Spectral Library - pyrophyllite; chlorite; jarosite; and copiapite.

- An evaporation pan for mine process water, known to contain elevated concentrations of uraniumbearing minerals (mostly in the form of uraninite and uranyl sulphate complexes).

Pyrophyllite and chlorite are primary minerals (white micas) associated with gold-bearing reef (ore), and we therefore considered them signatures of bulk tailings transport. Sulphide minerals on the surface of mine residues become oxidised, yielding efflorescence with sulphates and metal cations. Secondary minerals formed in this manner include jarosite and copiapite (Naicker et al., 2003), which we considered signatures of water-borne contamination and AMD. Uraninite occurs as both a primary and secondary mineral; therefore the uranium-bearing minerals could indicate bulk tailings material or AMD. It was also recognised that all five minerals could be associated with reef outcrops and their natural weathering.

The distribution of live vegetation was mapped using the NDVI (Tucker, 1979). Metadata were obtained from the EMM and the Gauteng Department of Agriculture, Conservation and Environment (GDACE). These included GIS shapefiles of geology, streams, dams, wetlands and land use.

\subsection{Categorisation and Extent of Mine Residue}

We used the aerial photographs and Chamber of Mines Dump Indexes to categorise MRDs in terms of type, status and footprint type (Table 2). They were further classified using the GDACE and EMM spatial data in terms of underlying geology, proximity to residential areas, watercourses, and agricultural lands (Table 3). From the 2003 aerial photographs we plotted the extent of contamination on the soil surface by slimes and/or salt crusts. Since different types of MRDs were often built directly adjacent to, or on top of, each another it was not possible to assign contamination to a particular MRD. Therefore, a grid was laid out encompassing all of the MRDs and containing 58 blocks; each measuring $4 \times 4 \mathrm{~km}$ (Figure 1a). Block size was determined from the size of the mining belt, size and proximity of MRDs, and extent of contamination. The identification of contamination was based on colour, shape and location. To identify any change in extent of contamination over time we selected 11 of the 58 blocks using random numbers, giving a 19\% sample size, and plotted contamination for 1938 and 1964. Paired sample t-tests were used to compare spillage between the various years.

\subsection{Association between ASTER-detectable Minerals and Mine Residue, Land-Use or Normalised Difference Vegetation Index (NDVI)}

We used $2 \times 2$ contingency tables, and in some cases odds ratios, to examine associations or possible lack of independence between ASTER-detectable minerals and different forms of mine residue (e.g. Figures $1 \mathrm{~b}$ to e), categories of agricultural land-use and NDVI. When any of the observed counts in the contingency table equalled zero, thereby making the odds ratio equal to zero, 0.5 was added to each cell before calculating the odds ratio (Agresti, 1996). For all tests, significance was taken at the $5 \%$ level.

\section{$3 \quad$ RESULTS}

\subsection{Examination of Aerial Photography}

\subsubsection{Categorisation and extent of mine residue}

The EMM covers an area of some 192339 ha of which 16917 ha or $8.8 \%$ is zoned as mining. MRDs, past and present, cover an area of 7956.5 ha (4.1\%) with slimes dams and footprints totalling 6742.4 ha (3.5\%) occupying the majority of this area. From the series of aerial photographs we found that $53 \%$ of gold mine residue deposits were situated within $100 \mathrm{~m}$ of a watercourse with $52 \%$ of these (i.e. $27 \%$ of the total) built within the watercourse. An unknown number were situated on old wetlands and pans. We also found that $64 \%$ of slimes dams had failed and there were instances of failures and spillage in 1938 being virtually 
unchanged in 1964 (Figure 2). The aerial photographs depicted massive sedimentation of streams and channels due to residues from these failures.

We also found that $15 \%$ of MRDs were constructed on dolomites. Historically, it was considered advantageous to site MRDs on dolomites to improve drainage and consequently, dump stability. A further perceived advantage is dolomite's neutralising effect, as the component magnesium carbonate is acidsoluble. However, Hodgson et al. (2001) concluded that widening of pathways could occur, resulting in greater transmissivity and storage volumes; and also that stability problems could result from karstification.

Table 2 Mine Residue Deposits within the Ekurhuleni Metropolitan Municipality (EMM)

\begin{tabular}{|c|c|c|c|c|c|c|}
\hline \multicolumn{7}{|c|}{ Mine Residue Deposits : Area (hectares) } \\
\hline TYPE & STATUS & $\begin{array}{c}\text { Number of } \\
\text { (N) }\end{array}$ & Median & Minimum & Maximum & Total \\
\hline All MRDs & Total & 287 & 9.7 & 0.4 & 893.1 & 7956.5 \\
\hline \multirow[t]{2}{*}{ Calcine dam } & Sub total & 1 & 28.7 & 28.7 & 28.7 & 28.7 \\
\hline & Dormant & 1 & 28.7 & 28.7 & 28.7 & 28.7 \\
\hline \multirow{3}{*}{$\begin{array}{l}\text { Slimes constructed } \\
\text { feature }\end{array}$} & Sub total & 4 & 6.2 & 5.7 & 56.9 & 74.9 \\
\hline & Dam wall & 1 & 5.7 & 5.7 & 5.7 & 5.7 \\
\hline & Land infill & 3 & 6.3 & 6.1 & 56.9 & 69.3 \\
\hline \multirow[t]{2}{*}{ Overburden } & Sub total & 7 & 3.4 & 1.4 & 4.2 & 20.5 \\
\hline & Active & 7 & 3.4 & 1.4 & 4.2 & 20.5 \\
\hline \multirow[t]{7}{*}{ Sand dump } & Sub total & 42 & 10.9 & 0.5 & 36.8 & 525.1 \\
\hline & Dormant & 7 & 15.3 & 3.8 & 18.4 & 89.7 \\
\hline & Reworking & 14 & 22.2 & 5.0 & 36.8 & 295.8 \\
\hline & Footprints - Total & 21 & 5.2 & 0.5 & 16.5 & 139.6 \\
\hline & - Paddocks & 2 & 9.9 & 3.3 & 16.5 & 19.9 \\
\hline & - Developed & 4 & 3.6 & 1.2 & 8.1 & 16.5 \\
\hline & - Free draining & 15 & 8.7 & 0.5 & 14.4 & 103.2 \\
\hline \multirow[t]{9}{*}{ Rock dump } & Sub total & 101 & 4.1 & 0.4 & 19.6 & 564.9 \\
\hline & Dormant & 4 & 4.8 & 1.2 & 5.2 & 16.1 \\
\hline & Dam wall & 1 & 11.5 & 11.5 & 11.5 & 11.5 \\
\hline & Reworking & 16 & 8.2 & 2.8 & 19.6 & 147.6 \\
\hline & Footprint-Total & 80 & 2.5 & 0.4 & 18.5 & 389.7 \\
\hline & - Embankment & 1 & 5.4 & 5.4 & 5.4 & 5.4 \\
\hline & - Paddocks & 1 & 9.1 & 9.1 & 9.1 & 9.1 \\
\hline & - Developed & 11 & 2.2 & 0.9 & 4.5 & 25.6 \\
\hline & - Free draining & 67 & 2.8 & 0.4 & 18.5 & 349.6 \\
\hline \multirow[t]{8}{*}{ Slimes dam } & Sub total & 132 & 20.9 & 0.4 & 893.1 & 6742.4 \\
\hline & Active & 9 & 82.7 & 19.3 & 893.1 & 1476.7 \\
\hline & Dormant & 31 & 31.4 & 1.9 & 145.1 & 1488.3 \\
\hline & Reworking & 39 & 24.9 & 0.5 & 577.0 & 2073.3 \\
\hline & Footprint-Total & 53 & 14.5 & 0.4 & 226.2 & 1704.0 \\
\hline & - Paddocks & 12 & 11.8 & 2.3 & 59.2 & 201.3 \\
\hline & - Developed & 6 & 7.0 & 2.7 & 75.2 & 116.1 \\
\hline & - Free draining & 35 & 16.3 & 0.4 & 226.2 & 1386.6 \\
\hline
\end{tabular}

Almost all (95\%) MRDs were found within $1000 \mathrm{~m}$ of residential areas; with $81 \%$ within $500 \mathrm{~m}$. Impacts of dust from MRDs include what is termed 'nuisance', as well as respiratory problems. In South Africa, most MRDs are unfenced and thus used for recreation (e.g. quad-bikers), and as informal playgrounds by children. This informal use of MRDs presents a potential risk to both the users and owners. In addition to increasing erosion and dust emissions, the increased hand-to-mouth activity (and ingestion of particles) exhibited by young children is known to place this population group at particularly high risk of metal toxicity (World Health Organization, 2001). 
A third (35\%) of MRDs are located within $1000 \mathrm{~m}$ of agricultural land; with a quarter (23\%) within $500 \mathrm{~m}$. Impacts of dust from MRDs include acidification and salinisation of soils, whereas impacts on crops include smothering, toxicity and reduced yield. It is well established that some plant species can accumulate metals to potentially toxic levels (Marschner, 1995) and that plants on tailings and AMD have elevated metal contents (Weiersbye et al., 1999; Weiersbye \& Witkowski; 2003). The recent death of a child in Johannesburg from multiple metal-poisoning is thought to be as a result of consuming a herbal remedy (Steenkamp et al., 2002). The ingested metals were typical of gold MRD's, and found to be present in a range of herbal medicines (Steenekamp et al., 2005).
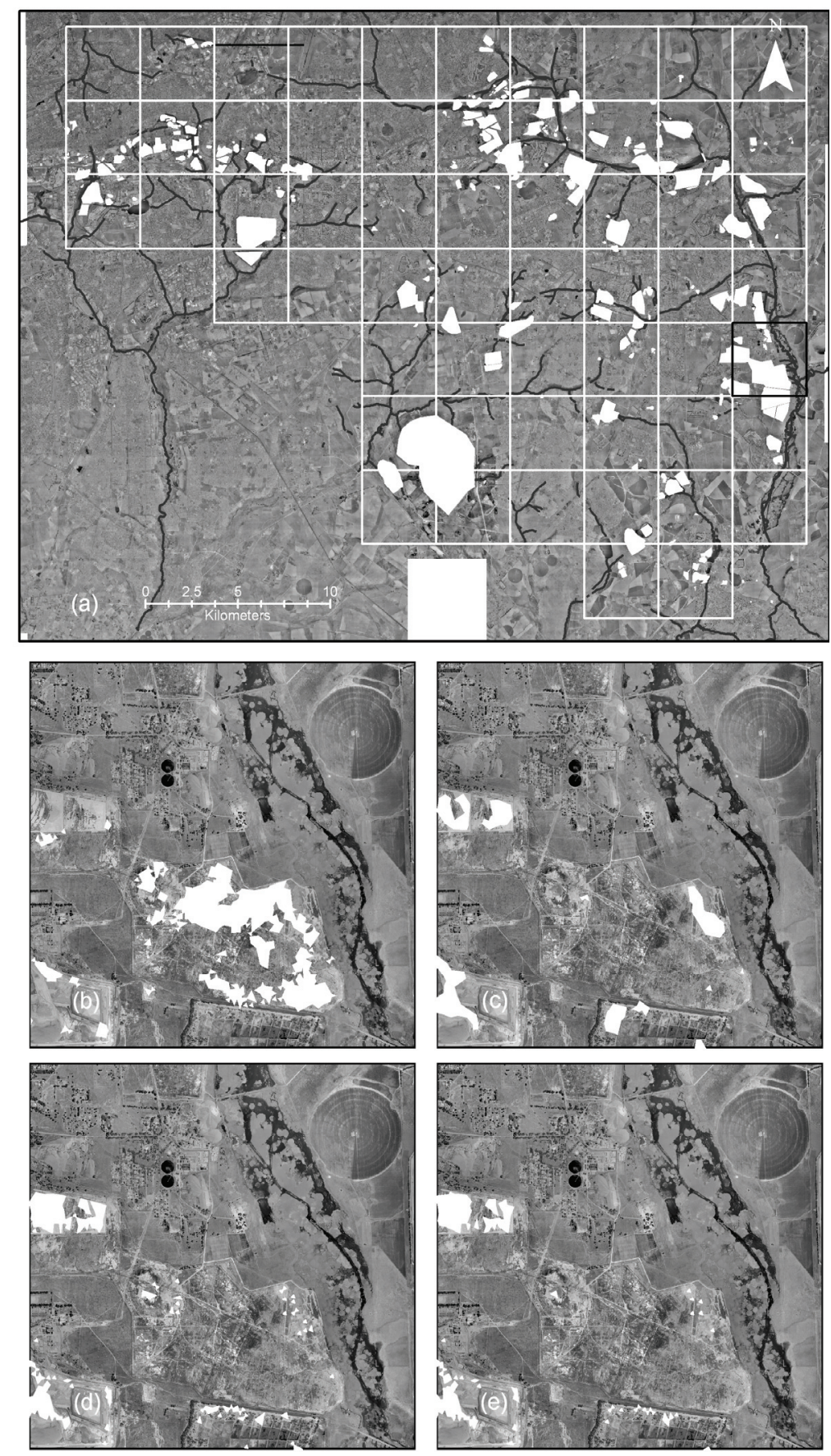

Figure 1 Aerial photographs (2003) showing: (a) sampling grid on the main study area with MRDs indicated in white and a single sampling block outlined in black; (b) - (e) show ASTER-detectable minerals within the black outlined block, (b) uranium-bearing; (c) jarosite; (d) pyrophyllite; and (e) copiapite 
Table 3 Proximity of mine residue deposits to sensitive areas

\begin{tabular}{|l|r|r|}
\hline \multicolumn{1}{|c|}{ Situation $(\mathbf{N = 2 8 7 )}$} & Number & \multicolumn{1}{c|}{ \% } \\
\hline In watercourse & 78 & 27 \\
\hline Within 100 m of watercourse & 151 & 53 \\
\hline On dolomites & 42 & 15 \\
\hline Located in residential area & 33 & 11 \\
\hline Within 500 m of residential area & 233 & 81 \\
\hline Within 1000 m of residential area & 274 & 95 \\
\hline Located in agricultural area & 6 & 2 \\
\hline Within 500 m of agricultural area & 65 & 23 \\
\hline Within 1000 m of agricultural area & 100 & 35 \\
\hline
\end{tabular}
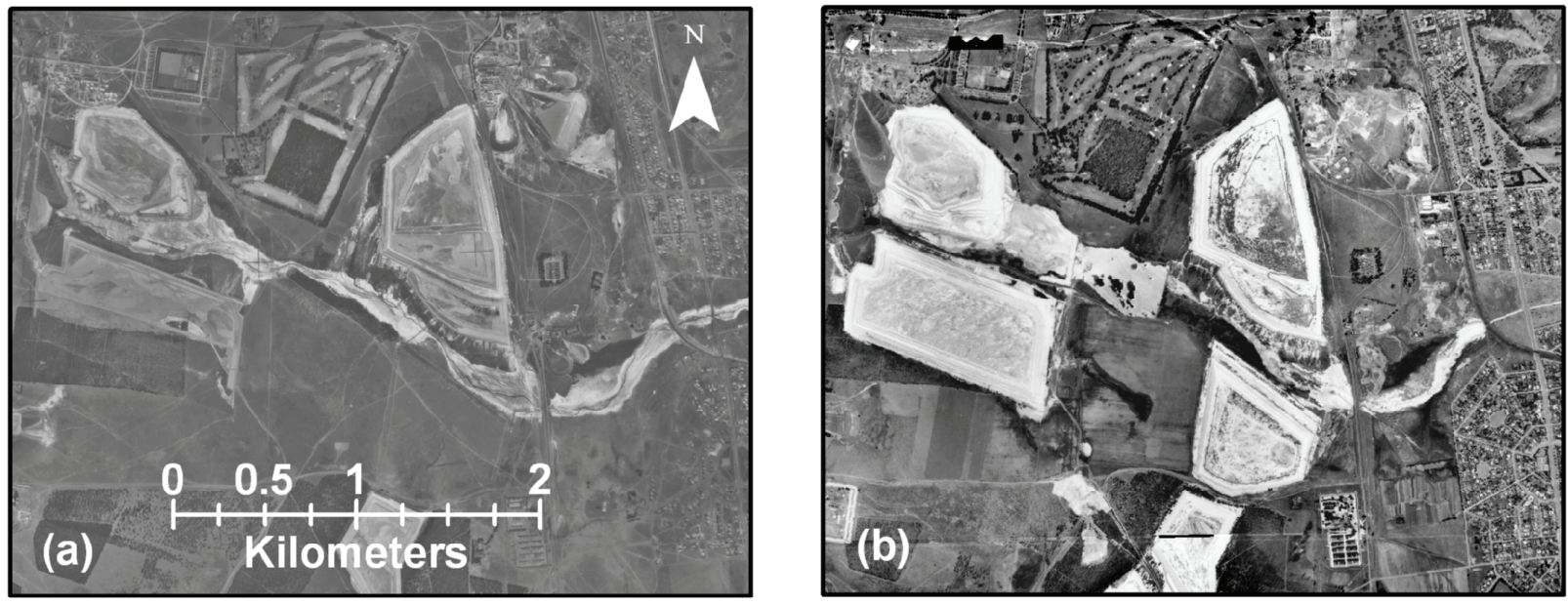

Figure 2 MRD sidewall failures and spillage into a watercourse in (a) 1938 and (b) 1964

\subsubsection{Plotting of visible residue contamination}

Spillage plotted from the 2003 aerial photographs covers 1175 ha ( $0.6 \%$ of EMM). From the sub-sample of 11 blocks selected randomly (Table 4) we determined that there was a significant increase between 1938 and 1964 and a significant decrease between 1964 and 2003 (paired sample t-tests: $p=0.0424$ and 0.0018 respectively). We suggest that the increase from 1938 to 1964 was due to increased mining activity and continued absence of pollution control measures, whereas the decrease between 1964 and 2003 could have several reasons, including: improved legislation resulting in basic pollution control measures; reprocessing of old dumps and some spillages; development masking spillages; and masking by eroded soil, organic matter and vegetation.

Table 4 Summary statistics of spillage (in hectares) within a sub-sample of 11 random blocks detected from aerial photographs taken in 1938, 1964 and 2003

\begin{tabular}{|r|r|r|l|r|r|r|r|r|}
\hline Year & N & Mean & $\begin{array}{l}\text { Std } \\
\text { Dev }\end{array}$ & Total & \multicolumn{1}{|c|}{$\begin{array}{c}\text { Lower 95\% } \\
\text { Confidence Limit } \\
\text { for Mean }\end{array}$} & $\begin{array}{c}\text { Upper 95\% } \\
\text { Confidence Limit } \\
\text { for Mean }\end{array}$ & t Value & Pr $>|\mathbf{t}|$ \\
\hline 1938 & 11 & 40.7 & 41.1 & 447.9 & 13.1 & 68.3 & 3.28 & 0.0082 \\
\hline 1964 & 11 & 65.3 & 59.6 & 718.1 & 25.2 & 105.3 & 3.63 & 0.0046 \\
\hline 2003 & 11 & 30.5 & 42.3 & 335.8 & 2.1 & 58.9 & 2.39 & 0.0377 \\
\hline
\end{tabular}




\subsection{Association between Mine Residue and ASTER-Detectable Minerals}

We found positive associations $(p<0.0001)$ between four of the five minerals detected by ASTERS and all gold mine tailings (i.e. MRDs and spillage) detected from aerial photographs; the exception being chlorite (Table 5). Associations were greatest for slimes dams (i.e. active, dormant and being reworked). There was a positive association only between uranium-bearing minerals and slimes dam footprints $(p<0.0001)$ with two other minerals that are known to be present having a negative association (jarosite at $p=0.0127$ and copiapite at $\mathrm{p}=0.0116$ ). Thus the aerial photographs appear to be a more reliable indicator of residual tailings material than ASTER thematic imagery of minerals (Figure 3, arrow a).

After removing the influence of MRDs, positive associations were found between spillages and all minerals except chlorite. These relationships were weak, with less than $2 \%$ of spillage associated with any of the minerals detected by ASTER. Since most of these minerals are known to be present, this indicates that the ASTER sensor is either not sensitive enough for these particular minerals at low concentrations, or that the minerals were not detectable as a result of the influence of water (i.e. primary minerals are masked by moisture, while many secondary minerals only form as precipitates (Figure 3, arrow b).

Table $5 \quad$ Results of contingency tables examining the association between minerals detected by ASTERS and mine residue detected from aerial photographs

\begin{tabular}{|c|c|c|c|c|c|c|c|}
\hline \multirow[b]{2}{*}{$\begin{array}{l}\text { FEATURE } \\
(\mathbf{2 0 0 3 )}\end{array}$} & \multirow[b]{2}{*}{ MINERAL } & \multicolumn{3}{|c|}{ Including MRDs } & \multicolumn{3}{|c|}{ Excluding MRDs } \\
\hline & & $\begin{array}{c}\text { \%o of } \\
\text { feature } \\
\text { showing } \\
\text { mineral }\end{array}$ & $\begin{array}{c}\text { \% of } \\
\text { surrounding } \\
\text { area showing } \\
\text { mineral } \\
\end{array}$ & $p$ & $\begin{array}{c}\text { \% of } \\
\text { feature } \\
\text { showing } \\
\text { mineral }\end{array}$ & $\begin{array}{c}\text { \% of } \\
\text { surrounding } \\
\text { area showing } \\
\text { mineral } \\
\end{array}$ & $p$ \\
\hline \multirow{5}{*}{$\begin{array}{l}\text { All Tailings } \\
\text { (including } \\
\text { spillage) }\end{array}$} & Uranium-bearing & 13.94 & 0.22 & $<0.0001$ & & & \\
\hline & Jarosite & 24.05 & 0.06 & $<0.0001$ & & & \\
\hline & Pyrophyllite & 11.73 & 0.08 & $<0.0001$ & & & \\
\hline & Copiapite & 11.39 & 0.20 & $<0.0001$ & & & \\
\hline & Chlorite & 0.01 & 0.02 & 0.6962 & & & \\
\hline \multirow{5}{*}{$\begin{array}{l}\text { Slimes Dams } \\
\text { (active, } \\
\text { dormant and } \\
\text { reworking) }\end{array}$} & Uranium-bearing & 19.27 & 0.35 & $<0.0001$ & & & \\
\hline & Jarosite & 35.05 & 0.19 & $<0.0001$ & & & \\
\hline & Pyrophyllite & 16.35 & 0.19 & $<0.0001$ & & & \\
\hline & Copiapite & 15.85 & 0.30 & $<0.0001$ & & & \\
\hline & Chlorite & 0.02 & 0.02 & 0.9423 & & & \\
\hline \multirow{5}{*}{$\begin{array}{l}\text { Slimes Dam } \\
\text { Footprints }\end{array}$} & Uranium-bearing & 8.16 & 1.26 & $<0.0001$ & & & \\
\hline & Jarosite & 1.23 & 2.12 & 0.0127 & & & \\
\hline & Pyrophyllite & 0.98 & 1.07 & 0.7185 & & & \\
\hline & Copiapite & 0.49 & 1.16 & 0.0116 & & & \\
\hline & Chlorite & 0.00 & 0.02 & 0.5711 & & & \\
\hline \multirow{5}{*}{ Spillage } & Uranium-bearing & 1.77 & 1.40 & 0.3206 & 1.77 & 0.30 & $<0.0001$ \\
\hline & Jarosite & 1.57 & 1.93 & 0.4117 & 1.57 & 0.11 & $<0.0001$ \\
\hline & Pyrophyllite & 1.15 & 0.88 & 0.3704 & 1.15 & 0.07 & $<0.0001$ \\
\hline & Copiapite & 1.25 & 0.96 & 0.3564 & 1.25 & 0.18 & $<0.0001$ \\
\hline & Chlorite & 0.00 & 0.05 & 0.4903 & 0.00 & 0.05 & 0.4783 \\
\hline
\end{tabular}




\subsection{Association between Minerals and Land Use}

We found that uranium-bearing minerals were only detectable on irrigated agricultural land, and not on rainfed agriculture, with over $6 \%$ of irrigated land showing uranium-bearing minerals (Table 6 ). The odds ratio of there being uranium-bearing minerals on this irrigated land was 960.21 times greater than for rain-fed, indicating that the possible uranium source was the irrigation water used for crops (Figure 4a). Irrigation water in the region comes from rivers and groundwater; both of which could be in receipt of natural uranium sources (e.g. reef outcrops or aquifers intersecting uranium-bearing reefs) as well as mining sources (e.g. dewatering or AMD). Our findings support those of Tutu et al. (2005) and Winde et al. (2004), both of whom found substantial evidence for the accumulation of various uranium-bearing minerals in areas of high evapotranspiration along rivers and streams across the Witwatersrand Basin. Mineral signatures that we considered typical of gold residue deposits and AMD, such as jarosite and uranium-bearing minerals, were also associated with reef outcrops (Figure $4 \mathrm{~b}$ ).

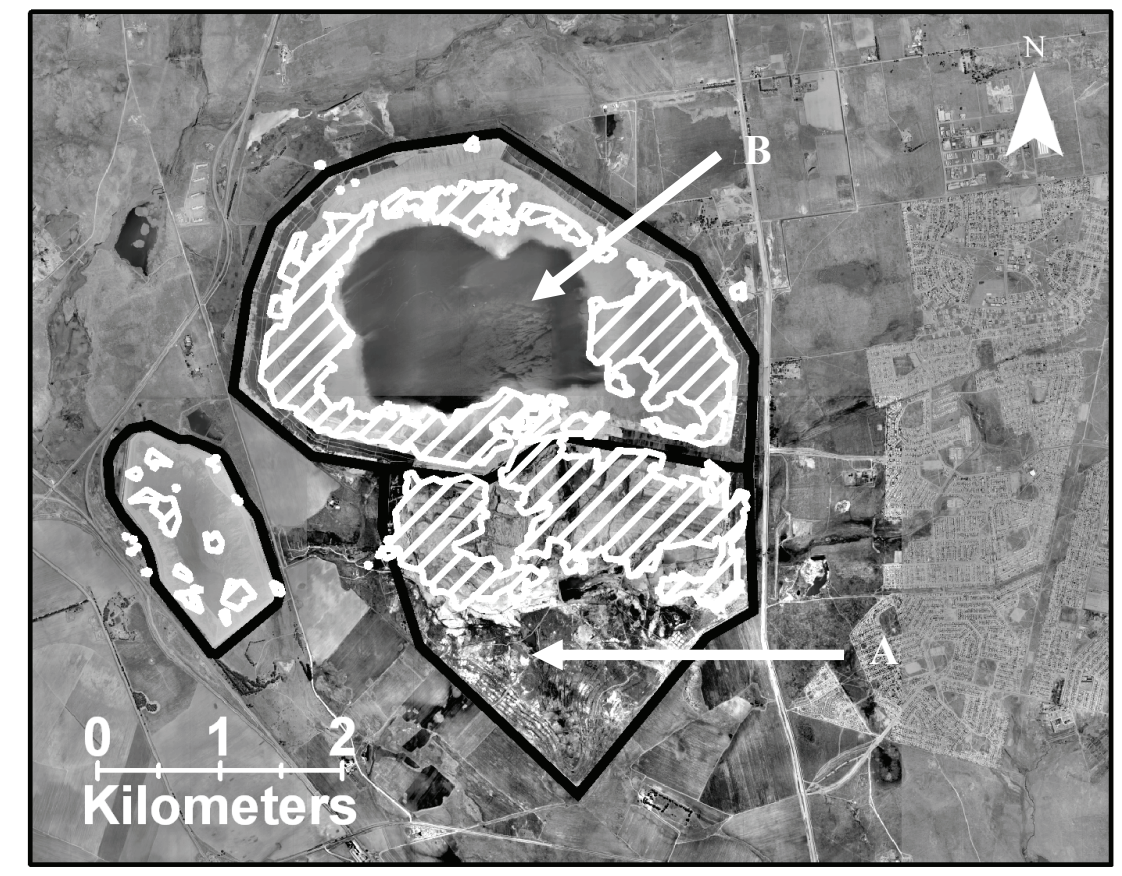

Figure 3 Aerial photograph of a partially removed slimes dam showing the presence of residue on the 'cleaned' part of the footprint (arrow A) whereas ASTER only detects minerals, including uranium-bearing minerals (white stripes), on the un-cleared part. Arrow B shows how water masks detection of minerals

Table 6 Result of contingency tables for association between minerals and agriculture

\begin{tabular}{|l|c|c|c|c|}
\hline \multicolumn{1}{|c|}{ MINERAL } & $\begin{array}{c}\text { Irrigated Agriculture } \\
\text { \% showing mineral }\end{array}$ & $\begin{array}{c}\text { Rain Fed Agriculture } \\
\text { \% showing mineral }\end{array}$ & $\boldsymbol{p}$ & Odds Ratio \\
\hline $\begin{array}{l}\text { Uranium- } \\
\text { bearing }\end{array}$ & 6.18 & 0.00 & $<0.0001$ & 960.21 \\
\hline Jarosite & 0.33 & 0.01 & $<0.0001$ & 23.95 \\
\hline Pyrophyllite & 0.00 & 0.00 & - & - \\
\hline Copiapite & 0.00 & 0.00 & - & - \\
\hline Chlorite & 1.24 & 0.03 & $<0.0001$ & 45.31 \\
\hline
\end{tabular}



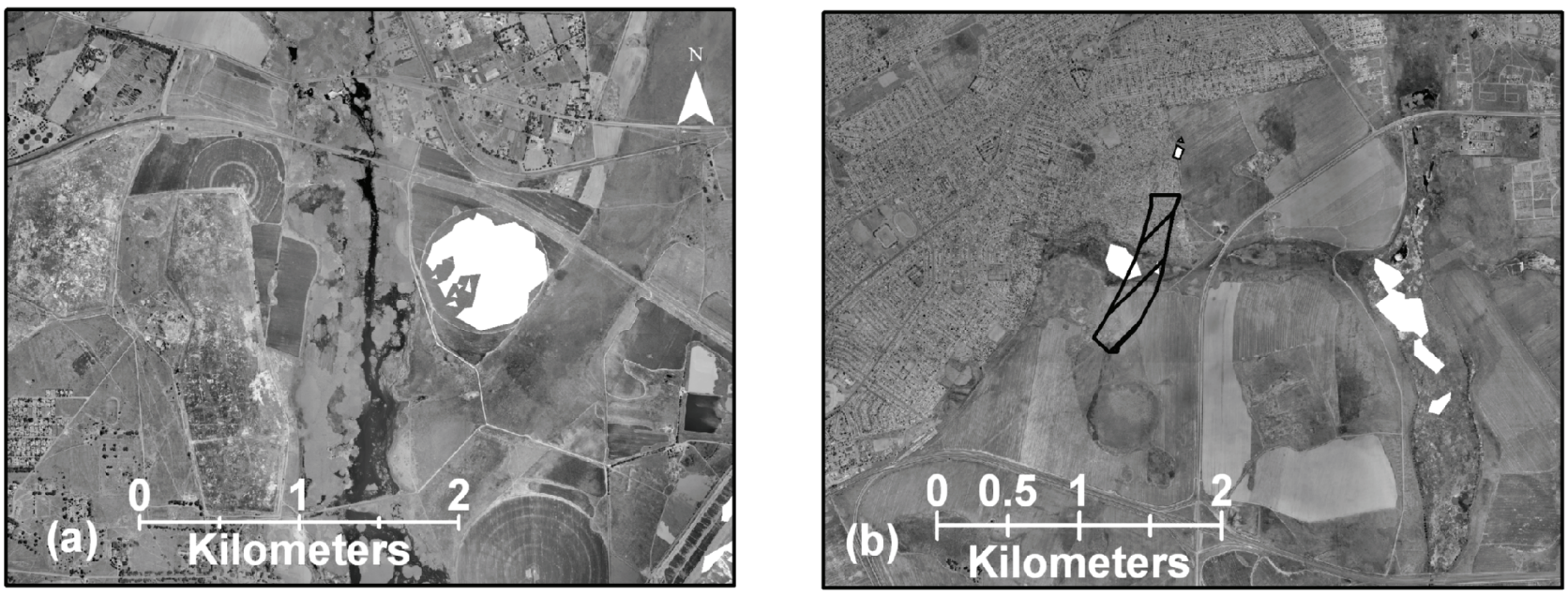

Figure 4 Aerial photographs (2003) with thematic overlay showing uranium-bearing minerals (solid white) on (a) irrigated agricultural land (a crop pivot) and (b) Black Reef outcrop (black stripes)

\subsection{Association between Minerals and NDVI}

We found a positive association between NDVI and both uranium-bearing minerals and chlorite and a negative association with each of jarosite, pyrophyllite and copiapite $(\mathrm{p}<0.0001)$ (Table 7). The odds ratio of there being uranium-bearing minerals or chlorite on land with live vegetation was, respectively, 2.92 and 589.61 times greater than for land with either no or dormant vegetation. This indicates that spectra of uranium-bearing minerals and chlorite are not heavily masked by vegetation, whereas the other mineral spectra may be, and supports the argument for transport of uranium-bearing minerals by water.

Table $7 \quad$ Results of contingency tables for assessing the effect of vegetation (detected using NDVI) on ASTER-detection of minerals

\begin{tabular}{|l|c|c|r|}
\hline MINERAL & \% of vegetation (NDVI) with mineral & $\boldsymbol{p}$ & \multicolumn{1}{c|}{ Odds Ratio } \\
\hline Uranium-bearing & 3.75 & $<0.0001$ & 2.92 \\
\hline Jarosite & 0.54 & $<0.0001$ & 0.27 \\
\hline Pyrophyllite & 0.03 & $<0.0001$ & 0.03 \\
\hline Copiapite & 0.00 & $<0.0001$ & 0.02 \\
\hline Chlorite & 1.35 & $<0.0001$ & 589.61 \\
\hline
\end{tabular}

\subsection{Identified Contamination}

\subsubsection{Aerial photography}

We found aerial photographs a useful indicator of mine residue. However, interpretation requires substantial skills and local knowledge. The following are potential sources of error:

- Colour - Some roofs of buildings and land cleared for construction were the same scale of grey as residues. However, buildings were easily identified and excluded.

- Location - If the colour and shape resembled mine residue, and was contiguous with a MRD, or in close proximity, then it was generally judged to be tailings. 


\subsubsection{ASTER imagery}

We found ASTER imagery useful for identifying previously unknown "hot spots" remote from likely sources. These included the irrigation pivots mentioned earlier, contamination downstream from sources, reef outcrops and a formal residential area some $13 \mathrm{~km}$ from the nearest gold mining activity. This residential area was associated with significant areas of uranium-bearing minerals and jarosite, possibly as a result of former land-use (irrigated agricultural land), and/or proximity to the Black Reef (Figure 5).
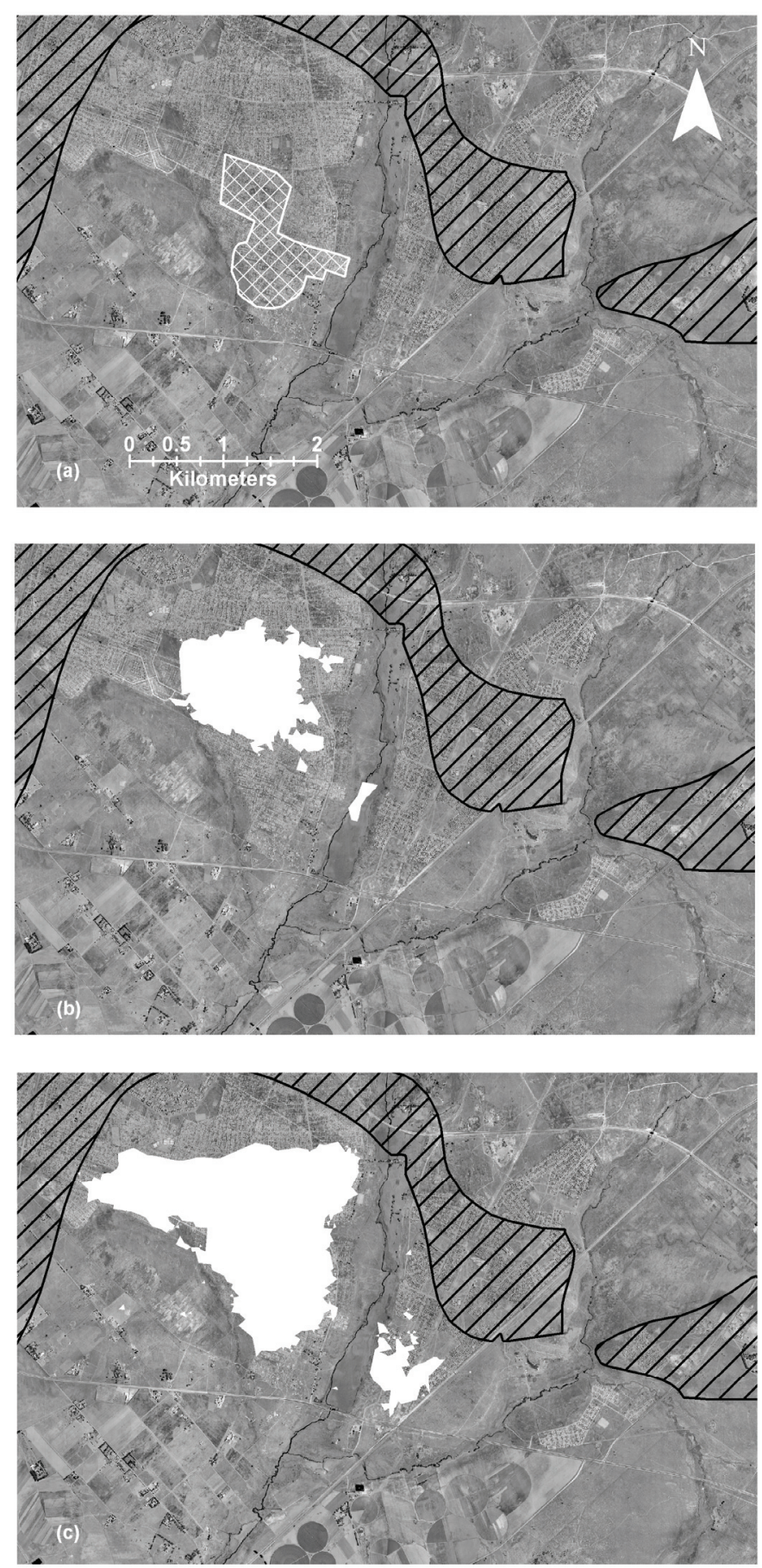

Figure 5 Aerial photographs (2003) of (a) former agricultural holdings (now residential) (white cross stripes), with ASTER thematic overlays in solid white for (b) jarosite and (c) uranium-bearing minerals. The presence of the black reef is indicated in black stripes 


\section{CONCLUSION}

We found that 120 years of gold mining have caused significant alteration and contamination of watercourses and soils; much of it easily visible from historical aerial photographs. ASTER imagery proved valuable in indicating the presence of contamination some distance from the probable sources that was otherwise undetectable by aerial photography. The locations and associations of the detectable minerals indicate that contamination from natural reef outcrops and gold mining is wide-spread, and that the waterborne pathway for dissemination of pollutants is extensive - as proposed by Naiker et al., (2003); Tutu et al. (2003; 2005) and Winde et al. (2004). However, the exact source(s) and pathways require more clarification, as does the assessment of geochemisty under different land-use scenarios in order to quantify potential risk.

The extent of physical mine residues visible on surface has markedly reduced since 1964. It appears that the removal of numerous MRDs (some 1704 ha of slimes dams cleared by 2003 and a further 2073 ha being reworked) for reprocessing and consolidation into a few super dumps between the late 1970s and present day on the East Rand, may have reduced future pollution risk simply by consolidation of the sources.

This study also illustrates the importance of establishing a sound baseline of environmental conditions prior to commencing with a mining project, and for obtaining agreement with the regulator on the extent of responsibilities and liabilities for site closure. Where a baseline was not established, the analysis of a combination of histoical aerial photographs and remote sensing data can assist in retrofitting an approximate baseline to provide a starting point for negotiations.

\section{ACKNOWLEDGEMENTS}

We are grateful to the Council for Geosciences for making available the 1938 photographs, and to GDACE and the EMM for access to spatial planning databases. AngloGold Ashanti Ltd is thanked for support of MW Sutton's MSc. We also appreciate the contributions of two anonymous reviewers to this paper.

\section{REFERENCES}

Agresti, A. (1996) An introduction to categorical data analysis. Wiley, New York.

Chevrel, S., Courant, C., Cottard, F., Coetzee, H., Bourguignon, A. and Ntsume, G. (2003) Very high resolution remote sensing coupled to GIS-based environmental assessment - East Rand goldfield, South Africa. Report BRGM/RP-52724-FR.

Hodgson, F.D.I., Usher., B.H., Scott, R., Zeelie, S., Cruywagen, L-M. and de Necker, E. (2001) Prediction techniques and preventative measures relating to the post-operational impact of underground mines on the quality and quantity of groundwater resources. WRC Report No. 699/1/01.

Maree, J.P., van Tonder, G.J. and Millard, P. (1996) Underground Neutralisation of Mine Water with Limestone. Report to the Water Research Commission by the Division of Water, Environment and Forestry Technology, CSIR WRC Report No 609/1/96, 51 p.

Marschner, H. (1995) Mineral Nutrition of Higher Plants. Second Edition. Academic Press, London, 889 p.

Mphephu, N.F., Viljoen, M.J. and Annegarn, H.J. (2003) Geochemistry of mine tailings and contribution to soil and water pollution on the Central Rand. In Implementing sustainable development in mining: From talk to action. Chamber of Mines of South Africa, Mining and Sustainable Development Conference, Sandton, 3-5 November, 7C-9 to $7 \mathrm{C}-15$.

Naicker, K., Cukrowska, E. and McCarthy, T.S. (2003) Acid mine drainage arising from gold mining activity in Johannesburg, South and environs. Journal of Environmental Pollution. 122, pp. 29-40.

Richter, R. (2003) ATCOR 2.3 User guide. DLR- German Aerospace Center, Remote Sensing data center, Wessling, Germany.

Steenekamp, V., Stewart, M. and Cukrowska, E.M. (2002) A severe case of multiple metal poisoning in a child treated with a traditional medicine. Forensic Science International 3397, pp. 1-4.

Steenekamp, V., Stewart, M., Chimuka, L. and Cukrowska, E.M. (2005) Uranium concentrations in South African herbal remedies, Health Physics, 2005 89(6), pp. 679-683. 
Tucker, C.J. (1979) Red and Photographic Infrared Linear Combinations for Monitoring Vegetation. Remote Sensing of the Environment 8, pp. 127-150.

Tutu, H., Cukrowska, E.M., McCarthy, T.S., Mphephu, N.F. and Hart, R. (2003) Determination and modelling of geochemical speciation of uranium in gold mine polluted land in South Africa. In: Proceedings: 8th International Congress on Mine Water and the Environment, Johannesburg, South Africa, pp. 137-155.

Tutu, H., Cukrowska, E.M., Dohnal, V. and Havel, J. (2005) Application of artificial neural networks for classification of uranium distribution in the central Rand goldfield, South Africa. Environmental Modelling and Assessment, 10, pp. 143-152.

World Health Organisation. (2001) Environmental Health Criteria. WHO, Geneva.

Weiersbye, I.M., Straker, C.J. and Przybylowicz, W. (1999). Micro-PIXE mapping of elemental distribution in arbuscular mycorrhizal roots of the grass, Cynodon dactylon, from gold and uranium mine tailings. Nuclear Instruments and Methods in Physics Research B 158, pp. 335-343.

Weiersbye, I.M. and Witkowski, E.T.F. (2003). Acid rock drainage (ARD) from gold tailings dams on the Witwatersrand Basin impacts on tree seed fate, inorganic content and morphology. In: Proceedings: 8th International Congress on Mine Water and the Environment, Johannesburg, South Africa, pp. 311-328.

Winde, F., Wade, P. and van der Walt, I.J. (2004) Gold tailings as a source of waterborne uranium contamination of streams - The Koekemoerspruit (Klerksdorp goldfield, South Africa) as a case study. Part I of III: Uranium migration along the aqueous pathway. Water SA 30(2), pp. 219-225.

Witkowski, E.T.F. and Weiersbye, I.M. (1998) Variation in geochemistry and soil features of South African gold slimes dams and adjacent soils. Plant Ecology and Conservation Series No. 6, Report to the Anglo-American Corporation, $111 \mathrm{p}$. 